Biol. Stud. 2012: 6(3); 15-28 • DOI: https://doi.org/10.30970/sbi.0603.235

www.http://publications.Inu.edu.ua/journals/index.php/biology

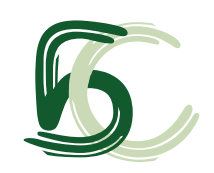

UDC 577.112.7:616

\title{
HYPOXIC REGULATION OF THE EXPRESSION OF ANTI-ANGIOGENIC GENES IN U87 GLIOMA CELLS WITH LOSS OF FUNCTION OF ERN1 SIGNALING ENZYME
}

\author{
K. I. Kubaichuk ${ }^{1}$, D. O. Minchenko, ${ }^{1,2}$, S. V. Danilovskyi ${ }^{1}$, \\ A. Y. Kuznetsova' ${ }^{1}$ A. K. Jasim ${ }^{1}$, O. H. Minchenko 1 \\ ${ }^{1}$ Palladin Institute of Biochemistry, NAS of Ukraine, 9, Leontovych St., Kyiv 01601, Ukraine \\ ${ }^{2}$ O.O. Bohomoletz National Medical University, 13, Shevchenko Boulvd., Kyiv 01601, Ukraine \\ e-mail: ominchenko@yahoo.com
}

The angiogenesis is an important component of tumor growth and tightly associated with hypoxia. The expression level of genes related to regulation of angiogenesis (BAI2, SPARC, TIMP1, TIMP2, TIMP3, TIMP4, THBS1, THBS2, ADAMTS5 and FGF2) in glioma U87cells and cells with suppressed function of signaling enzyme ERN1, a major mediator of the endoplasmic reticulum stress by qPCR, was studied. We have shown that the expression of genes encoding BAI2, SPARC, TIMP2, TIMP3, THBS1 and THBS2 is strongly increased in glioma cells with ERN1 signaling enzyme loss of function, being more intense for TIMP2, TIMP3 and THBS1 genes. At the same time, the expression of genes encoding TIMP1, TIMP4, ADAMTS5 and FGF2 is significantly decreased with more strong effect for ADAMTS5 and TIMP4 genes. At hypoxia, the expression of most of studied genes in both glioma cell types is affected. Hypoxia induced the expression of TIMP1, TIMP3 and ADAMTS5 genes both in control glioma cells and cells with ERN1 enzyme loss of function. However, the effect of hypoxia towards TIMP2 gene expression was observed only in control glioma cells. At the same time, the expression of genes encoding BAI2, SPARC, THBS1, THBS2, ADAMTS5 and FGF2 is decreased under hypoxia action, but its expression mostly depended on ERN1 signaling enzyme function. The results of this study provide strong evidence that suppression of ERN1 signaling enzyme function, as well as hypoxia, affects the expression of genes related to regulation of angiogenesis in glioma cells. It is suggested that changes in the expression of these genes contribute to a suppression of glioma cells' proliferation by blockade of functioning of ERN1 signaling enzyme.

Keywords: gene expression, BAI2, SPARC, TIMP1, TIMP2, TIMP3, TIMP4, THBS1, THBS2, ADAMTS5, FGF2, ERN1, glioma cells, hypoxia. 


\section{INTRODUCTION}

The endoplasmic reticulum stress plays an important role in tumor growth. It is an obligatory component of tumorigenesis, as well as hypoxia and angiogenesis. Moreover, the malignant tumors use the endoplasmic reticulum stressing for activation of the proliferative processes partially through the enhancement of an angiogenesis and suppression of apoptosis, in parallel to knockdown of the tumor suppression genes [1, 2]. Different factors, including hypoxia, have been shown to induce complex intracellular signaling events known as the unfolded protein response which is mainly mediated by endoplasmic reticulum to nuclei-1 signaling enzyme (ERN1; also named as inositol requiring enzyme-1alpha, IRE1) in order to adapt cells for survival or, alternatively, to enter cell death programs through the endoplasmic reticulum-associated machineries [3-5]. As such, it participates in the early cellular response to the accumulation of misfolded proteins in the lumen of the endoplasmic reticulum [2]. The endoplasmic reticulum stress is contributed to the expression profile of many regulatory genes resulting in proliferation, angiogenesis and apoptosis [6, 7].

Two distinct catalytic domains of the bifunctional signaling enzyme ERN1 were identified: a serine/threonine kinase and an endoribonuclease which contribute to ERN1 signalling. The ERN1-associated kinase activity autophosphorylates and dimerizes this enzyme, leading to the activation of its endoribonuclease domain, degradation of a specific subset of mRNA and initiation of the pre-XBP1 (X-box binding protein 1) mRNA splicing $[6,8,9]$. Mature XBP1 mRNA splice variant encodes a transcription factor that stimulates the expression of hundreds of unfolded protein response-specific genes [6, $10]$. Thus, a known role of the spliced form of XBP1 in metabolic processes is its ability to act as a transcription factor regulating the expression of genes that increase the endoplasmic reticulum folding capacity, thereby improving cell surviving. Moreover, XBP1s has additional functions, especially in the regulation of glucose homeostasis $[11,12]$. Thus, the p38 MAP kinase phosphorylates the spliced form of XBP1 and significantly enhances its nuclear migration [11]. Moreover, the regulatory subunits of phosphatidyl inositol 3-kinase interact with XBP1 and also increase its nuclear translocation [13]. Zhou et al. [12] shown that XBP1s interacts with the Forkhead box O1 (FOXO1) transcription factor and directs it toward the proteasome-mediated degradation.

The endoplasmic reticulum stress response-signalling pathway is associated with hypoxia and linked to the neovascularization process and tumor growth since the complete blockade of ERN1 signal transduction pathway had anti-tumor effects preferentially via a suppression of VEGFA [14, 15]. The malignant tumor angiogenesis is regulated by different, tightly interconnected factors. However, matrix proteins with pleiotropic roles which are linked to tumor growth represent special interest because of revealed anti-angiogenic properties and a capacity to regulate cell proliferation [16-22].

Thrombospondin 1 (THBS1 or TSP1) is an adhesive glycoprotein that mediates cell-to-cell interactions, has anti-angiogenic properties and inhibits of cell growth [17]. It was shown that decorin which antagonizes the angiogenic network induces the expression of thrombospondin-1 and tissue inhibitor of matrix metalloproteinase 3 (TIMP3), but inhibits vascular endothelial growth factor A (VEGFA) [16]. Moreover, the endothelial nitric oxide synthase controls the expression of the angiogenesis inhibitor thrombospondin 2 and ADAM metallopeptidase with thrombospondin type 1 motif, 5 (ADAMTS5).

ISSN 1996-4536 • Біологічні Студії / Studia Biologica • 2012 • Том 6/№3 • С. 15-28 
There are four genes encoded tissue inhibitor of matrix metalloproteinase with different regulatory properties. TIMP1 is a potent inhibitor of tumor growth and angiogenesis, but is also able to promote cell proliferation in a wide range of cell types. TIMP2 has a unique role among TIMP family members in its ability to directly suppress the proliferation of endothelial cells.

The enhanced neovascularization correlated with down-regulation of anti-angiogenic THBS1 and related proteins, such as connective tissue growth factor (CTGF) [21]. Moreover, VEGFA binds connective tissue growth factor and that its angiogenic activity is inhibited in the VEGFA-CTGF complex form; however, stability of this complex, as well as the angiogenic activity of VEGF depends from matrix metalloproteinases and its inhibitors [22]. The brain-specific angiogenesis inhibitor 2 (BAI2) inhibits the ischemiainduced brain angiogenesis [23].

SPARC is a pleiotropic protein, has anti-angiogenic properties and appears to regulate cell growth [24]. The endoplasmic reticulum stress is recognized as an important determinant of tumor growth and mainly contributes to the expression profile of genes controlling angiogenesis; however, a detailed molecular mechanism of the angiogenesis regulation is not yet clear and remains to be determined. It is important in studying the role of ERN1 signaling pathways in tumor progression for developing a new understanding concerning molecular mechanisms of malignant tumors progression in relation to hypoxia and defines the best targets for the design of specific inhibitors that could act as potent antitumor drugs.

The main goal of this work was to study the role of the expression of genes related to the regulation of angiogenesis (BAI2, SPARC, TIMP1, TIMP2, TIMP3, TIMP4, THBS1, THBS2, ADAMTS5 and FGF2) in glioma U87 cells for evaluation of its significance in suppressing tumor growth through a blockade of the EREN1 signaling enzyme functioning.

\section{MATERIALS AND METHODS}

Cell lines and culture conditions. The glioma cell line U87 was obtained from ATCC (U.S.A.) and grown in high glucose (4,5 g/l) Dulbecco's modified Eagle's minimum essential medium (Gibco, Invitrogen, USA) supplemented with glutamine (2 mM), $10 \%$ fetal bovine serum (Equitech-Bio,Inc., USA), penicillin (100 units/ml; Gibco) and streptomycin $\left(0.1 \mathrm{mg} / \mathrm{ml}\right.$; Gibco) at $37^{\circ} \mathrm{C}$ in a $5 \% \mathrm{CO} 2$ incubator. In this work we used two sublines of this glioma cell line. One subline was obtained by selection of stable transfected clones with overexpression of vector, which was used for creation of dnERN1. This untreated subline of glioma cells (control glioma cells) was used as control 1 in the study of the effect of hypoxia and glutamine or glucose deprivations on the expression level of genes related to regulation of angiogenesis. Second subline was obtained by selection of stable transfected clones with overexpression of ERN1 dominant/negative constructs ( $\mathrm{n} E \mathrm{RN} 1$ ) and has suppressed both protein kinase and endoribonuclease activities of this signaling enzyme [14]. The level of expression of studied genes in these cells was compared with such level in cells transfected by the vector (control 1). That sub-line was also used as control 2 for investigation of the effect of hypoxia and glutamine or glucose deprivations on the expression level of genes related to regulation of angiogenesis under blockade ERN1 enzyme function. 
Hypoxic conditions were created in special incubator with $3 \%$ oxygen and $5 \%$ carbon dioxide levels; culture plates with complete DMEM were exposed to these conditions for 16 hrs.

The functional activity of ERN1 signaling enzyme in glioma cells that over-expresses a dominant-negative construct of endoplasmic reticulum-nuclei-1 (dnERN1) was estimated by analysis of the expression of XBP1 alternative splice variant (XBP1s), a key transcription factor in ERN1 signaling, and phosphorylated isoform of ERN1 in cells under endoplasmic reticulum stress condition induced by tunicamycin $(0.01 \mathrm{mg} / \mathrm{ml}$ during 2 hrs) [25].

RNA isolation. Total RNA was extracted from different tumor tissues and normal tissue counterparts, as described previously назвати принцип методу [25]. RNA pellets were washed with $75 \%$ ethanol and dissolved in nuclease-free distilled water.

Reverse transcription and quantitative real-time polymerase chain reaction analysis. The expression levels of brain-specific angiogenesis inhibitor 2 (BA/2), fibroblast growth factor 2 (FGF2), secreted protein acidic and rich in cysteine (SPARC), tissue inhibitor of matrix metalloproteinase 1-4 (TIMP1-TIMP4), thrombospondin 1 and 2 (THBS1 and THBS2), ADAM metallopeptidase with thrombospondin type 1 motif, 5 (ADAMTS5) and secreted protein acidic and rich in cysteine (SPARC) mRNAs were measured in glioma cell line U87 and its subline with a deficiency of ERN1 by quantitative polymerase chain reaction of cDNA using „Mx 3000P QPCR” (Stratagene, U.S.A.) and SYBRGreen Mix (AB gene, Great Britain). QuaniTect Reverse Transcription Kit (QIAGEN, Germany) was used for cDNA synthesis as described previously [25]. Polymerase chain reaction was performed in triplicate. For amplification of $B A / 2$ CDNA was used forward (5'-CATTGTCCTGGTGAACATGC-3' and reverse (5'-TGCACAGCAGTGATGACAAA-3') primers. The nucleotide sequences of these primers correspond to sequences 3612 3631 and 3959-3940 of human BA/2 cDNA (GenBank accession number NM_001703). The size of amplified fragment is $348 \mathrm{bp}$. The amplification of FGF2 cDNA for real time $\mathrm{RCR}$ analysis was performed using two oligonucleotides primers: forward - 5'-AGAGCGACCCTCACATCAAG-3' and reverse - 5'-ACTGCCCAGTTCGTTTCAGT-3'. The nucleotide sequences of these primers correspond to sequences 571-590 and 804-785 of human FGF2 cDNA (GenBank accession number NM_002006). For amplification of TIMP1 CDNA we used forward (5'-AATTCCGACCTCGTCATCAG-3' and reverse (5'-TGCAGTTTTCCAGCAATGAG-3') primers. The nucleotide sequences of these primers corresponds to sequences 301-320 and 530-511 of human TIMP1 cDNA (GenBank accession number NM_003254). The size of amplified fragment is $230 \mathrm{bp}$. The amplification of TIMP2 cDNA was performed using forward primer (5'-GATGCACATCACCCTCTGTG-3') and reverse primer (5'-GTCGAGAAACTCCTGCTTGG-3'). These oligonucleotides correspond to sequences 665-684 and 950-931 of human TIMP2 cDNA (GenBank accession number NM_003255). The size of amplified fragment is $286 \mathrm{bp}$. Two other primers were used for real time RCR analysis of the expression of TIMP3 CDNA: forward -5'-CTGACAGGTCGCGTCTATGA-3' and reverse-5'-GGCGTAGTGTTTGGACTGGT-3'. The nucleotide sequences of these primers correspond to sequences 14961515 and 1735-1716 of human TIMP3 cDNA (GenBank accession number NM_000362). The size of amplified fragment is $240 \mathrm{bp}$. For amplification of TIMP4 cDNA we used forward (5'-CAGACCCTGCTGACACTGAA-3' and reverse (5'-AGACTTTCCCTCTGCAC-

ISSN 1996-4536 • Біологічні Студії / Studia Biologica • 2012 • Том 6/№3 • С. 15-28 
CAA-3') primers. The nucleotide sequences of these primers correspond to sequences 696-715 and 954-935 of human TIMP4 cDNA(GenBank accession numberNM_003256). The size of amplified fragment is $259 \mathrm{bp}$. For real time RCR analysis of THBS1 cDNA expression we used next primers: forward - 5'-TTCTACGAGCTGTGGCAATG-3' and reverse - 5'-TTTCTTGCAGGCTTTGGTCT-3'. The nucleotide sequences of these primers correspond to sequences 1352-1371 and 1637-1618 of human THBS1 cDNA (GenBank accession number NM_003246). The size of amplified fragment is $286 \mathrm{bp}$. The amplification of THBS2 cDNA was performed using forward primer (5'-AGCGTCAGATGTGCAACAAG-3') and reverse primer (5'-CTTGTCCTTGCATGGGTTTT-3'). These oligonucleotides correspond to sequences 1864-1883 and 2213-2194 of human THBS2 cDNA (GenBank accession number NM_003247). The size of amplified fragment is $350 \mathrm{bp}$. The amplification of ADAMTS5 cDNA for real time RCR analysis was performed using two oligonucleotides primers: forward - 5'-GCCTGGAAGTGAGCAAGAAC-3' and reverse - 5'-TTTCGTGAGCCACAGTGAAG-3'. The nucleotide sequences of these primers correspond to sequences 1709-1728 and 1963-1944 of human ADAMTS5 cDNA (GenBank accession number NM_007038). The size of amplified fragment is $255 \mathrm{bp}$. The amplification of SPARC cDNA for qRCR analysis was performed using two oligonucleotides primers: forward -5'-TGCCTGATGAGACAGAGGTG-3' and reverse-5'-AAGTGGCAGGAAGAGTCGAA-3'. The nucleotide sequences of these primers correspond to sequences 176-195 and 479-460 of human SPARC cDNA (GenBank accession number NM_003118). The size of amplified fragment is $304 \mathrm{bp}$. The amplification of ACTB (beta-actin) cDNA was performed using forward - 5'-GGACTTCGAGCAAGAGATGG-3' and reverse - 5'-AGCACTGTGTTGGCGTACAG-3' primers. These primers nucleotide sequences correspond to 747-766 and 980-961 of human ACTB cDNA (GenBank accession number NM_001101). The size of amplified fragment is $234 \mathrm{bp}$. The expression of ACTB mRNA was used as control of analyzed RNA quantity. The primers were received from „Sigma” (USA). An analysis of quantitative PCR was performed using special computer program „Differential expression calculator” and statistical analysis - in Excel program. The values of BAI2, SPARC, TIMP1, TIMP2, TIMP3, TIMP4, THBS1, THBS2, ADAMTS5 and FGF2 mRNA expressions were normalized to the expression of beta-actin mRNA and represent as percent of control 1 (100\%). All values are expressed as mean \pm SEM from triplicate measurements performed in three independent experiments.

\section{RESULTS}

In this study, we found that genes related to the regulation of angiogenesis and proliferation are expressed in human glioma cell line U87, and the levels of their expression were dependent upon the ERN1 signaling enzyme functioning. Thus, the expression of $B A / 2$ gene in glioma cells deficient in signaling enzyme ERN1 is increased almost 4-fold as compared to control glioma cells (Fig. 1,A). An exposure of cells for 16 hrs to hypoxia did not change significantly the expression of $B A / 2$ gene in control glioma cells, but hypoxia inhibited its expression in cells with suppressed function of signaling enzyme ERN1 (Fig. 1, A). As shown in Fig. 1, $B$, the blockade of ERN1 enzyme function induced more that 4-fold the expression of SPARC gene. Moreover, the expression of that gene was also induced (approximately in 4-fold) by hypoxia, but only in control glioma cells. 


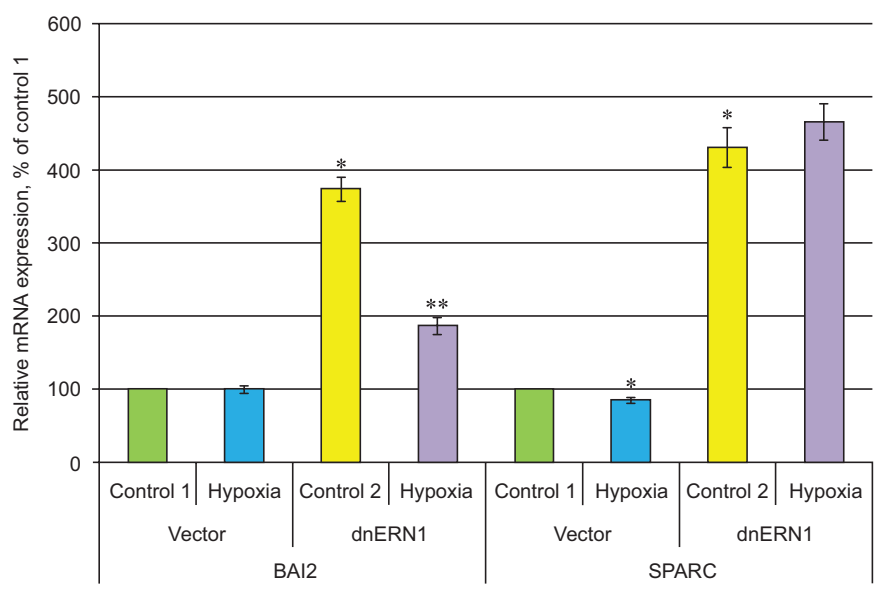

Fig. 1. Effect of hypoxia on the expression level of brain-specific angiogenesis inhibitor-2 (BA/2) and secreted protein acidic and rich in cysteine (SPARC) mRNA in glioma U87 cells (Vector) and its variant with suppressed function of ERN1 signaling enzyme (dnERN1). The values of BAI2 and SPARC mRNA expressions were normalized to the expression of beta-actin mRNA and are represented as a percent of control 1. Data are expressed as mean \pm SEM of values from each group; ${ }^{*}-\mathrm{P}<0.05$ versus control $1 ;{ }^{* *}-\mathrm{P}<0.05$ versus control 2

Рис. 1. Ефект гіпоксії на рівень експресії мРНК інгібітора ангіогенезу-2, специфічного для мозку (BAI2), та кислого і збагаченого на цистеїн протеїну, що секретується (SPARC), у клітинах гліоми лінії U87 (Vector) та її варіанта з пригніченою функцією сигнального ензиму ERN1 (dnERN1). 3начення експресії мРНК BAI2 та SPARC нормалізували за експресією мРНК бета-актину і представляли як відсоток від контролю 1. Результати виражали середнім значенням \pm SEM для кожної із груп; * - $\mathrm{P}<0,05$ порівняно 3 контролем 1; ** $-\mathrm{P}<0,05$ порівняно 3 контролем 2

At the same time, the expression of FGF2 and ADAMTS5 genes in glioma cells with ERN1 loss of function, as compared to control glioma cells, was strongly decreased 3- and 11-fold, correspondingly (Fig. 2). Hypoxia decreased the expression of FGF2 gene, but increased ADAMTS5 gene in both types of glioma cells, and the effect of hypoxia did not depend significantly on ERN1 signaling enzyme functioning.

Analysis of the expression of tissue inhibitor of matrix metalloproteinase genes in glioma cells with suppressed function of signaling enzyme ERN1 has shown that TIMP1 and TIMP4 gene expression is reduced as compared to control glioma cells (Fig. 3). However, the expression of TIMP2 and TIMP3 genes was strongly (more than 7-fold) increased (Fig. 4). An exposure of glioma cells for $16 \mathrm{hrs}$ to hypoxia led to an increase of TIMP1 and TIMP3 gene expressions in both types of studied glioma cells, independently on ERN1 enzyme function. However, much stronger effect of hypoxia (almost 3-fold) was shown for TIMP3 gene (Fig. 3 and 4). At the same time, the blockade the ERN1 signaling enzyme function completely eliminated the increasing effect of hypoxia on TIMP2 gene expression. No significant changes in the expression of TIMP4 gene were observed in both types of used glioma cells treated by hypoxia (Fig. 4).

As shown in Fig. 5, in glioma cells with ERN1 loss of function as compared to control glioma cells the expression of THBS1 and THBS2 genes is strongly increased, being more pronounced for THBS1 gene. No significant changes in the expression of THBS1 gene were observed in control glioma cells, but blockade of ERN1 signaling enzyme function led to a decrease of expression of that gene (Fig. 5, A). At the same time, the expression of THBS2 gene was decreased 2-fold in control glioma cells sub- 


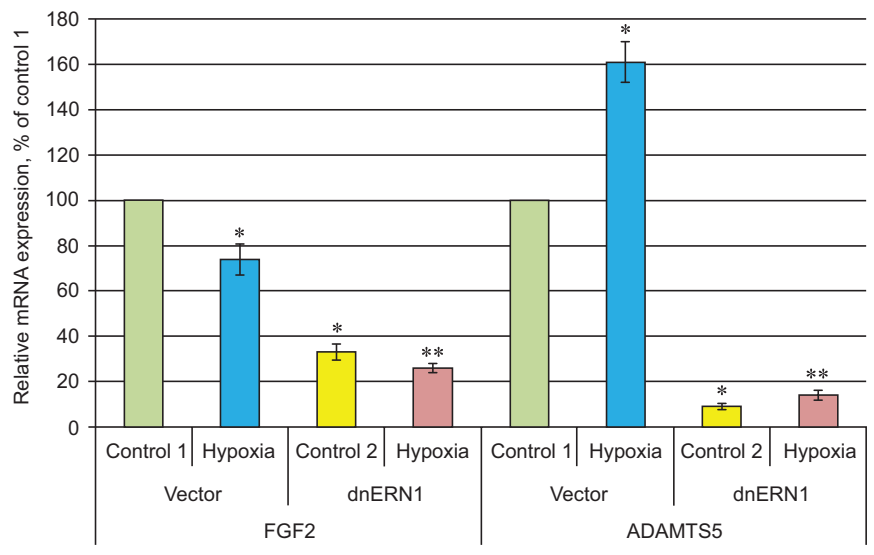

Fig. 2. Effect of hypoxia on the expression level of fibroblast growth factor 2 (FGF2) and ADAM metallopeptidase with thrombospondin type 1 motif, 5 (ADAMTS5) mRNA in glioma U87 cells (Vector) and its variant with suppressed function of ERN1 signaling enzyme (dnERN1). The values of FGF2 and ADAMTS5 mRNA expressions were normalized to the expression of beta-actin mRNA and are represented as a percent of control 1. Data is expressed as mean \pm SEM of values from each group; * $-\mathrm{P}<0.05$ versus control $1 ;{ }^{* *}-\mathrm{P}<0.05$ versus control 2

Рис. 2. Ефект гіпоксії на рівень експресії мРНК фрактора росту фрібробластів (FGF2) та ADAM металопептидази 5 з мотивом тромбоспондину типу 1 (ADAMTS5) у клітинах гліоми лінії U87 (Vector) та її варіанта з пригніченою функцією сигнального ензиму ERN1 (dnERN1). Значення експресії мPHK FGF2 і ADAMTS5 нормалізували за експресією мРНК бета-актину та представляли як відсоток від контролю 1. Результати виражали середнім значенням \pm SEM для кожної із груп; * - $\mathrm{P}<0,05$ порівняно $з$ контролем 1 ; ** $-\mathrm{P}<0,05$ порівняно $з$ контролем 2

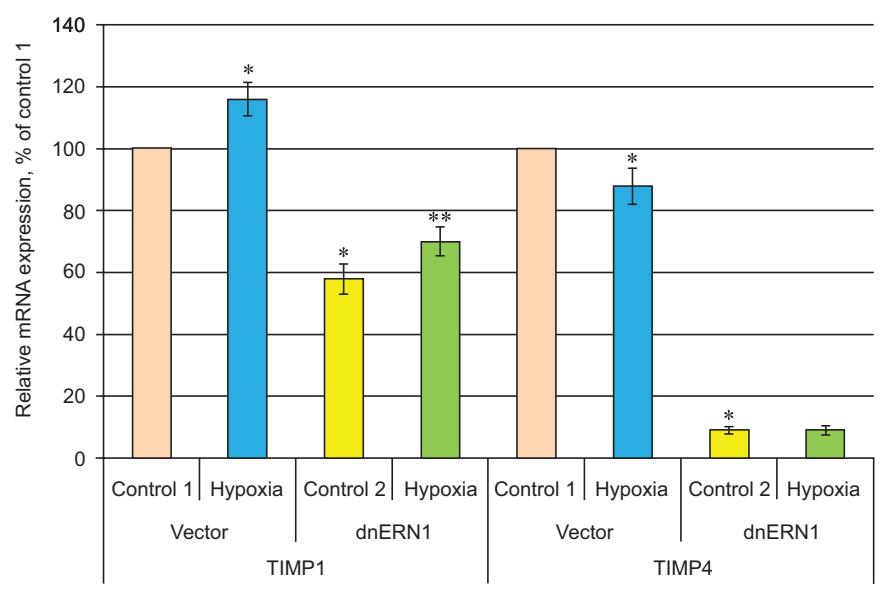

Fig. 3. Effect of hypoxia on the expression level of TIMP metallopeptidase inhibitor 1 and 4 (TIMP1 and TIMP4) mRNA in glioma U87 cells (Vector) and its variant with suppressed function of ERN1 signaling enzyme (dnERN1). The values of TIMP1 and TIMP4 mRNA expressions were normalized to the expression of beta-actin mRNA and are represented as a percent of control 1. Data is expressed as mean \pm SEM of values from each group; ${ }^{*}-\mathrm{P}<0.05$ versus control 1 ; ${ }^{* *}-\mathrm{P}<0.05$ versus control 2

Рис. 3. Ефект гіпоксії на рівень експресії мРНК інгібітора металопептидази TIMP 1 та 4 (TIMP1 та TIMP4) у клітинах гліоми лінії U87 (Vector) та її варіанта з пригніченою функцією сигнального ензиму ERN1 (dnERN1). Значення експресії мРHК TIMP1 та TIMP4 нормалізували за експресією мРНК бета-актину і представляли як відсоток від контролю 1. Результати виражали середнім значенням \pm SEM для кожної із груп; * $-\mathrm{P}<0,05$ порівняно з контролем 1 ; ** $-\mathrm{P}<0,05$ порівняно з контролем 2 


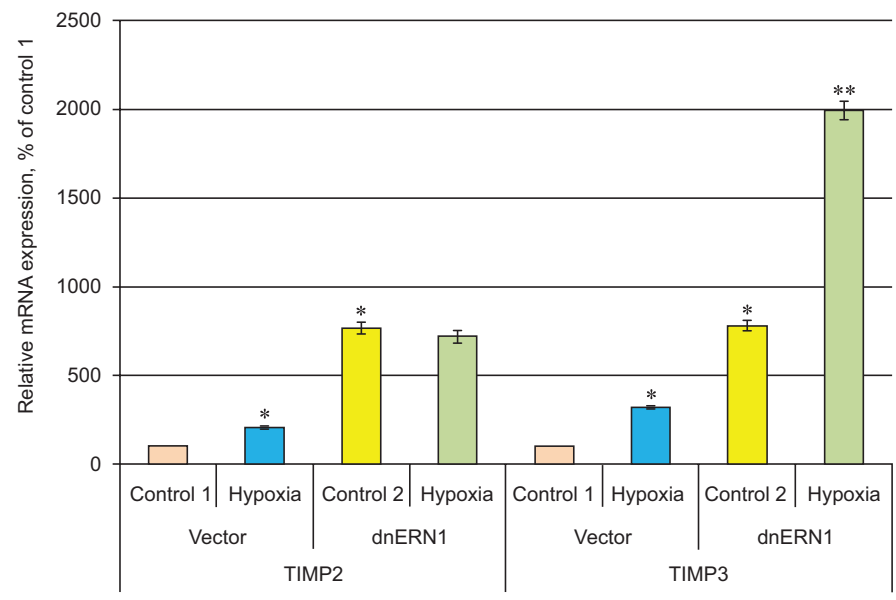

Fig. 4. Effect of hypoxia on the expression level of TIMP metallopeptidase inhibitor 2 and 3 (TIMP2 and TIMP3) mRNA in glioma U87 cells (Vector) and its variant with suppressed function of ERN1 signaling enzyme (dnERN1). The values of TIMP2 and TIMP3 mRNA expressions were normalized to the expression of beta-actin mRNA and are represented as a percent of control 1. Data is expressed as mean \pm SEM of values from each group; * $-\mathrm{P}<0.05$ versus control 1 ; ${ }^{*}-\mathrm{P}<0.05$ versus control 2

Рис. 4. Ефект гіпоксії на рівень експресії мРНК інгібітора металопептидази TIMP 2 та 3 (TIMP2 та TIMP3) у клітинах гліоми лінії U87 (Vector) та її варіанта з пригніченою функцією сигнального ензиму ERN1 (dnERN1). Значення експресії мРНК TIMP2 та TIMP3 нормалізували за експресією мРНК бета-актину і представляли як відсоток від контролю 1. Результати виражали середнім значенням \pm SEM для кожної із груп; * $-\mathrm{P}<0,05$ порівняно $з$ контролем 1 ; ** $-\mathrm{P}<0,05$ порівняно з контролем 2

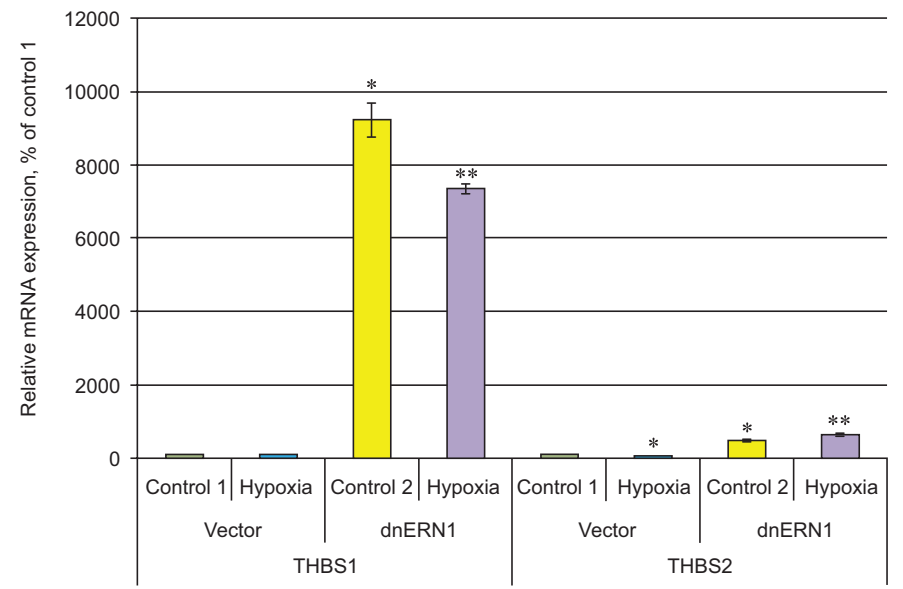

Fig. 5. Effect of hypoxia on the expression level of thrombospondin 1 and 2 (THBS1 and THBS2) mRNA in glioma U87 cells (Vector) and its variant with suppressed function of ERN1 signaling enzyme (dnERN1). The values of THBS1 and THBS2 mRNA expressions were normalized to the expression of beta-actin mRNA and are represented as a percent of control 1. Data is expressed as mean \pm SEM of values from each group; * $-\mathrm{P}<0.05$ versus control 1 ; ${ }^{* *}-\mathrm{P}<0.05$ versus control 2

Рис. 5. Ефект гіпоксії на рівень експресії мРНК тромбоспондину 1 та 2 (THBS1 та THBS2) у клітинах гліоми лінії U87 (Vector) та її варіанта з пригніченою функцією сигнального ензиму ERN1 (dnERN1). Значення експресії мРHК THBS1 та THBS2 нормалізували за експресією мРНК бета-актину і представляли як відсоток від контролю 1. Результати виражали середнім значенням \pm SEM для кожної із груп; * - $\mathrm{P}<0,05$ порівняно $з$ контролем 1 ; ${ }^{* *}-\mathrm{P}<0,05$ порівняно 3 контролем 2 
jected to hypoxia, but reverse changes in the expression of that gene in glioma cells with suppressed function of signaling enzyme ERN1 were observed (Fig. 5, B). Thus, a 2-fold increase in THBS2 gene expression was shown in the hypoxic condition in glioma cells with ERN1 loss of function.

\section{DISCUSSION}

We have demonstrated that the expression of different genes encoding for important regulatory factors controlling angiogenesis and growth processes, is dependent from endoplasmic reticulum stress signaling mediated by ERN1 enzyme. Angiogenesis is an important component of different proliferative processes, in particular, tumor growth. We studied the expression of genes mostly related to suppression of an angiogenesis and shown that blockade of ERN1 signaling enzyme function leads to a significant increase of the expression of BAI2, SPARC, TIMP2, TIMP3, THBS1 and THBS2 genes in glioma cells, besides that, the most significant increase was shown for TIMP2, TIMP3 and THBS1 genes. These findings are largely consistent with data from previous studies about the involvement of these genes in the regulation of different proliferative processes and angiogenesis [16, 17, 21, 23, 24]. Recently, it was shown that an integrin-binding N-terminal peptide region of TIMP-2 retains potent angio-inhibitory and antitumorigenic activity in vivo [19]. These data together with our results can explain suppression of glioma cell proliferation by blockade the ERN1 enzyme function [14, 15]. It is possible that a significant effect in suppression of this glioma cell proliferation contributes strong induction of brain-specific angiogenesis inhibitor 2 and SPARC gene expression, as well as both THBS genes, since both of them have strong anti-angiogenic properties and regulate cell growth $[23,24]$.

It should be noted that angiogenesis, like many other biological processes, is regulated by complex network of different factors which are tightly interconnected [16, 18, $20,21,23,25]$. Thus, thrombospondin-1, a matrix-bound adhesive glycoprotein, has been shown to modulate tumor progression and up-regulates tissue inhibitor of metalloproteinase-1 production in human tumor cells and also up-regulates matrix metalloproteinases MMP-2 and MMP-9 [18, 20]. These data suggest that the balance between matrix metalloproteinases and tissue inhibitors of metalloproteinases is a key determinant in different biological effects of THBS1, including tumor cell invasion, and may provide an explanation for the divergent activities reported for thrombospondin-1 in tumor progression.

Thus, the THBS1 is involved in affecting critical balance between MMPs and their inhibitors, maintaining the controlled degradation of the extracellular matrix needed to support tumor growth and metastasis in glioma cells where we find the overexpression of THBS1 as well as THBS2, TIMPs and other factors [18-22]. TIMP-2 is involved in binding to the receptor integrin $\alpha 3 \beta 1$ and mediates angio-inhibitory and tumor suppressor activity [19]. Moreover, the enhanced neovascularization correlated with down-regulation of anti-angiogenic connective tissue growth factor which binds VEGFA, and its angiogenic activity is inhibited in the VEGFA-CTGF complex form [22]. At the same time, stability of that complex, as well as the angiogenic activity of VEGF, depends on the matrix metalloproteinases and its inhibitors [21, 22].

It is possible that a significant reduction in the expression of ADAMTS5, FGF2 and TIMP4 showing pro-angiogenic properties also contributed to a suppression of prolifera- 
tion of the glioma cell with suppressed function of ERN1 signaling enzyme. Thus, the balance between different regulatory factors which participate in the control of angiogenesis, including vascular endothelial growth factor, a key pro-angiogenic factor, really determinate an angiogenesis in malignant tumors. As shown in Fig. 6, the regulation of angiogenesis by different factors (BAI2, FGF2, SPARC, ADAMTS5, TIMP1-4, THBS1, THBS2, endoplasmic reticulum stress and hypoxia) is complex and interconnected.

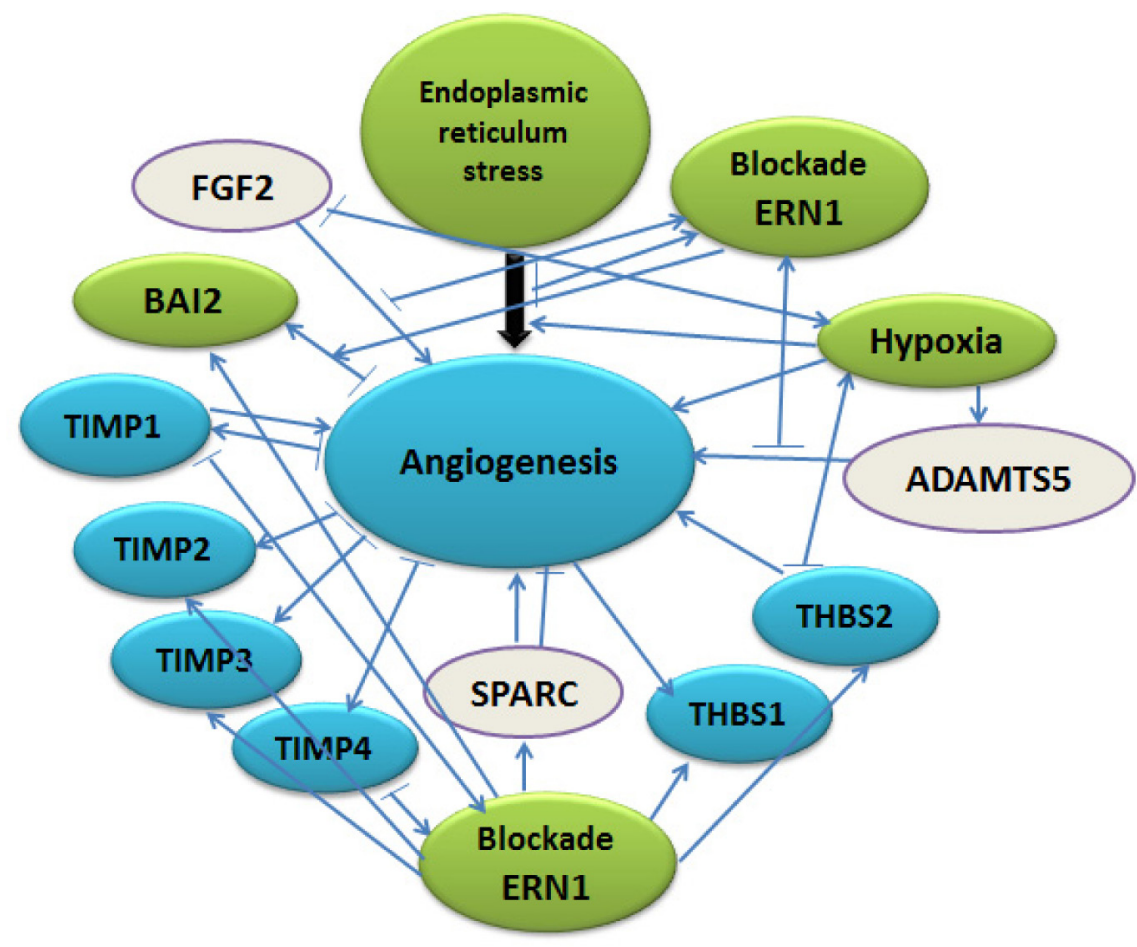

Fig. 6. Putative scheme of angiogenesis regulation by different factors, including BAI2, FGF2, SPARC, ADAMTS5, TIMP1-4, THBS1 and THBS2. Pleiotropic functions of TIMP1, TIMP4 and SPARC as well as the role of endoplasmic reticulum stress and function of ERN1, the main sensor and signaling enzyme mediated this stress, in the angiogenesis are shown

Рис. 6. Імовірна схема регуляції ангіогенезу різними фракторами, включаючи BAI2, FGF2, SPARC, ADAMTS5, TIMP1-4, THBS1 і THBS2. Показана плейотропна функція TIMP1, TIMP4 та SPARC, а також роль стресу ендоплазматичного ретикулуму та функції ERN1, основного сенсорно-сигнального ензиму, що опосередковує цей стрес, у ангіогенезі

Moreover, some of these factors possess pleiotropic functions. Most of these regulatory factors participated in the endoplasmic reticulum stress and its expression in normal and hypoxic conditions mainly depends on ERN1 signaling enzyme functioning. However, the precise molecular regulatory mechanisms of angiogenesis regulation remain unclear and require additional study. 


\section{CONCLUSIONS}

The results of this study provide strong evidence that the expression of genes encoding key regulatory factors related to the control of proliferation and angiogenesis in glioma cells with suppressed function of signaling enzyme ERN1 is deregulated. It is possible that changes in the expression of BAI2, SPARC, TIMPS, THBSs, ADAMTS5 and FGF2 genes in glioma cells can contribute to a suppression of tumor growth through modulation the angiogenesis, as well as proliferation. Thus, the obtained results underscore a crucial role of BAI2, SPARC, THBSs, TIMPs, ADAMTS5 and FGF2 in tumor progression and should be important for developing a new understanding concerning molecular mechanisms of malignant tumors growth in relation to the ERN1 signaling and hypoxia. They can also suggest the best targets for the design of specific inhibitors acting as potent antitumor drugs.

1. Moenner M., Pluquet O., Bouchecareilh M., Chevet E. Integrated endoplasmic reticulum stress responses in cancer. Cancer Research, 2007; 67(22): 10631-10634.

2. Zhang K., Kaufman R.J. Signaling the unfolded protein response from the endoplasmic reticulum. The Journal of Biological Chemistry, 2004; 279(25): 25935-25938.

3. Bi M., Naczki C., Koritzinsky M. et al. ER stress-regulated translation increases tolerance to extreme hypoxia and promotes tumor growth. The EMBO Journal, 2005; 24(19): 3470-3481.

4. Fels D.R., Koumenis C. The PERK/elF2- a/ATF4 module of the UPR in hypoxia resistance and tumor growth. Cancer Biology and Therapy, 2006; 5(7): 723-728.

5. Romero-Ramirez L., Cao H., Nelson D. et al. XBP1 is essential for survival under hypoxic conditions and is required for tumor growth. Cancer Research, 2004; 64(17): 5943-5947.

6. Hollien J., Lin J.H., Li H. et al. Regulated Ire1-dependent decay of messenger RNAs in mammalian cells. The Journal of Cell Biology, 2009; 186(3): 323-331.

7. Aragón T., van Anken E., Pincus $D$. et al. Messenger RNA targeting to endoplasmic reticulum stress signalling sites. Nature, 2009; 457(7230): 736-740.

8. Hetz C., Glimcher L.H. Fine-tuning of the unfolded protein response: Assembling the IRE1alpha interactome. Molecular Cell, 2009; 35(): 551-561.

9. Korennykh A.V., Egea P.F., Korostelev A.A. et al. The unfolded protein response signals through high-order assembly of Ire1. Nature, 2009; 457(): 687- 693.

10. Acosta-Alvear D., Zhou Y., Blais A. et al. XBP1 controls diverse cell type- and conditionspecific transcriptional regulatory networks. Molecular Cell, 2007; 27: 53-66.

11. Lee J., Sun C., Zhou Y. et al. p38 MAPK-mediated regulation of Xbp1s is crucial for glucose homeostasis. Nature Medicine, 2011; 17(10): 1251-1260.

12. Zhou Y., Lee J., Reno C.M. et al. Regulation of glucose homeostasis through a XBP-1-FoxO1 interaction. Nature Medicine, 2011; 17(3): 356-365.

13. Park S.W., Zhou Y., Lee J. et al. The regulatory subunits of PI3K, p85alpha and p85beta, interact with XBP-1 and increase its nuclear translocation. Nature Medicine, 2010; 16(4): 429-437.

14. Drogat B., Auguste P., Nguyen D.T. et al. IRE1 signaling is essential for ischemia-induced vascular endothelial growth factor-A expression and contributes to angiogenesis and tumor growth in vivo. Cancer Research, 2007; 67(14): 6700-6707.

15. Auf G., Jabouille A., Guérit $S$. et al. A shift from an an-giogenic to invasive phenotype induced in malignant glioma by inhibition of the unfolded protein response sen-sor IRE1. The Proceeding of the National Academy of Sciences of the United States of America, 2010; 107(35): 1555-1558. 
16. Neill T., Painter H., Buraschi S. et al. Decorin antagonizes the angiogenic network: concurrent inhibition of Met, hypoxia inducible factor 1alpha, vascular endothelial growth factor A, and induction of thrombospondin-1 and TIMP3. The Journal of Biological Chemistry, 2012; 287(8), 5492-5506.

17. Takahashi K., Mernaugh R.L., Friedman D.B. et al. Thrombospondin-1 acts as a ligand for CD148 tyrosine phosphatase. The Proceeding of the National Academy of Sciences of the United States of America, 2012; 109(6), 1985-1990.

18. John A.S., Hu X., Rothman V.L., Tuszynski G.P. Thrombospondin-1 (TSP-1) up-regulates tissue inhibitor of metalloproteinase-1 (TIMP-1) production in human tumor cells: exploring the functional significance in tumor cell invasion. Experimental and Molecular Pathology, 2009; 87(3):184-188.

19. Seo D.W., Saxinger W.C., Guedez L. et al. An integrin-binding N-terminal peptide region of TIMP-2 retains potent angio-inhibitory and anti-tumorigenic activity in vivo. Peptides, 2011; 32(9): 1840-1848.

20. Stetler-Stevenson W.G. Tissue inhibitors of metalloproteinases in cell signaling: metalloproteinase-independent biological activities. Science Signaling, 2008; 1: re6.

21. Dews M., Homayouni A., Yu D. et al. Augmentation of tumor angiogenesis by a Myc-activated microRNA cluster. Nature Genetics, 2006; 38(9): 1060-1065.

22. Hashimoto G., Inoki I., Fujii Y. et al. Matrix metalloproteinases cleave connective tissue growth factor and reactivate angiogenic activity of vascular endothelial growth factor 165 . The Journal of Biological Chemistry, 2002; 277(39): 36288-36295.

23. Kee H.J., Koh J.T., Kim M.Y. et al. Expression of brain-specific angiogenesis inhibitor 2 (BAI2) in normal and ischemic brain: involvement of BAI2 in the ischemia-induced brain angiogenesis. Journal of Cerebral Blood Flow and Metabolism, 2002; 22(9): 1054-1067.

24. Rivera L.B., Bradshaw A.D., Brekken R.A. The regulatory function of SPARC in vascular biology. Cellular and Molecular Life Sciences, 2011; 68(19): 3165-3173.

25. Minchenko D.O., Kubajchuk K.I., Hubenia O.V. et al. The effect of hypoxia and ischemic condition on the expression of VEGF genes in glioma U87 cells is dependent from ERN1 knockdown. Advances in Biological Chemistry, 2011; 2(2): 198-206.

\title{
РЕГУЛЯЦІЯ ЕКСПРЕСІЇ АНТИАНГІОГЕННИХ ГЕНІВ У КЛІТИНАХ ГЛІОМИ ЛІНІЇ U87 3 ВТРАЧЕНОЮ ФУНКЦІЄЮ СИГНАЛЬНОГО ЕНЗИМУ ЕRN1 ЗА УМОВ ГІПОКСІї
}

\author{
К. І. Кубайчук', Д. О. Мінченко, ${ }^{1,2}$ С. В. Даніловський \\ А. Ю. Кузнєцова ${ }^{1}$, А. К. Джассім ${ }^{1}$, О. Г. Мінченко \\ 1/нститут біохімії ім. О. В. Палладіна НАН України, вул. Леонтовича, 9, Київ 01601, Україна \\ ${ }^{2}$ Національний медичний університет ім. О. О. Богомольця, \\ бульв. Шевченка, 13, Київ 01601, Україна \\ e-mail: ominchenko@yahoo.com
}

Ангіогенез є важливим компонентом росту злоякісних пухлин і тісно пов'язаний з гіпоксією. Проведено дослідження рівня експресії генів, що мають відношення до ангіогенезу (BAI2, SPARC, TIMP1, TIMP2, TIMP3, TIMP4, THBS1, THBS2, ADAMTS5 та FGF2) у клітинах гліоми лінії U87 та клітинах із пригніченою функцією сигнального ензиму ERN1, основного медіатора стресу ендоплазматичного ретикулуму, за допомогою кількісної ПЛР. Показано, що експресія генів, які кодують синтез ВАІ2, SPARC, TIMP2, TIMP3, THBS1 та THBS2, суттєво збільшується у клітинах гліоми

ISSN 1996-4536 • Біологічні Студії / Studia Biologica • 2012 • Том 6/№3 • C. 15-28 
з пригніченою функцією сигнального ензиму ERN1, причому більш виражені зміни виявлені для генів TIMP2, TIMP3 та THBS1. У той же час, експресія генів, що кодують синтез TIMP1, TIMP4, ADAMTS5 та FGF2, суттєво знижується, але більш виражено - генів ADAMTS5 та TIMP4. Гіпоксія порушує експресію більшості досліджених генів в обох типах клітин гліоми. Так, гіпоксія індукує експресію генів TIMP1, TIMP3 та ADAMTS5 як у контрольних клітинах гліоми, так і у клітинах із пригніченою функцією ензиму ERN1, хоча ефект гіпоксії на експресію гена TIMP2 спостерігався лише у контрольних клітинах гліоми. У той же час експресія генів, що кодують синтез BAI2, SPARC, THBS1, THBS2, ADAMTS5 та FGF2, за гіпоксії знижується, але їх експресія переважно залежала від функції сигнального ензиму ERN1. Результати цього дослідження є суттєвим доказом того, що пригнічення функції сигнального ензиму ERN1, як і гіпоксія, змінюють експресію генів, що мають відношення до регуляції ангіогенезу у клітинах гліоми. Імовірно, що зміни в експресії цих генів роблять вклад у пригнічення проліферації клітин гліоми за умов блокади функції сигнального ензиму ERN1.

Ключові слова: експресія МРHК, гіпоксія, експресія мPHК, BAI2, SPARC, FGF2, TIMP1, TIMP2, TIMP3, TIMP4, THBS1, THBS2, ADAMTS5, клітини гліоми U87.

\title{
РЕГУЛЯЦИЯ ЭКСПРЕССИИ АНТИАНГИОГЕННЫХ ГЕНОВ В КЛЕТКАХ ГЛИОМЫ ЛИНИИ U87 БЕЗ ФУНКЦИИ СИГНАЛЬНОГО ЭНЗИМА ЕRN1 ПРИ ГИПОКСИИ
}

\author{
Е. И. Кубайчук 1 , Д. А. Минченко ${ }^{1,2}$, С. В. Даниловский' \\ А. Ю. Кузнєцова ${ }^{1}$, А. К. Джассим ${ }^{1}$, А. Г. Минченко \\ ${ }^{1}$ Институт биохимии им. А.В. Палладина НАН Украины \\ ул. Леонтовича, 9, Киев 01601, Украина \\ ${ }^{2}$ Национальный медицинский университет им. А. А. Богомольца, \\ бульв. Шевченко, 13, Киев 01601, Украина \\ e-mail: ominchenko@yahoo.com
}

Ангиогенез является важным компонентом роста злокачественных опухолей и тесно связан с гипоксией. Проведено исследование уровня экспрессии генов, которые имеют отношение к ангиогенезу (BAI2, SPARC, TIMP1, TIMP2, TIMP3, TIMP4, THBS1, THBS2, ADAMTS5 и FGF2) в клетках глиомы линии U87 и клетках с угнетенной функцией сигнального энзима ERN1, основного медиатора стресса эндоплазматического ретикулума, с помощью количественной ПЦР. Показано, что экспрессия генов, которые кодируют синтез BAI2, SPARC, TIMP2, TIMP3, THBS1 и THBS2, существенно увеличивается в клетках глиомы с угнетенной функцией сигнального энзима ERN1, причем более выраженные изменения выявлены для генов TIMP2, TIMP3 и THBS1. В то же время экспрессия генов, которые кодируют синтез TIMP1, TIMP4, ADAMTS5 и FGF2, существенно снижается, но более выражено - генов ADAMTS5 и TIMP4. Гипоксия нарушает экспрессию большинства исследованных генов в обоих типах клеток глиомы. Так, гипоксия индуцирует экспрессию генов TIMP1, TIMP3 и ADAMTS5 как в контрольных клетках глиомы, так 
и в клетках с угнетенной функцией энзима ERN1, хотя эффект гипоксии на экспрессию гена TIMP2 наблюдался лишь в контрольных клетках глиомы. В то же время экспрессия генов, которые кодируют синтез BAI2, SPARC, THBS1, THBS2, ADAMTS5 и FGF2, при гипоксии снижается, но их экспрессия преимущественно зависела от функции сигнального энзима ERN1. Результаты этого исследования являются существенным доказательством того, что угнетение функции сигнального энзима ERN1, как и гипоксия, изменяют экспрессию генов, которые имеют отношение к регуляции ангиогенеза в клетках глиомы. Вполне возможно, что изменения в экспрессии этих генов вносят вклад в угнетение пролиферации клеток глиомы при блокаде функции сигнального энзима ERN1.

Ключевые слова: гипоксия, экспрессия мPHК, BAI2, SPARC, FGF2, TIMP1, TIMP2, TIMP3, TIMP4, THBS1, THBS2, ADAMTS5, клетки глиомы U87.

Одержано: 14.09.2012 